\title{
EXTENSION OFFICERS' PERCEPTIONS OF EXTENSION AND INNOVATION IN SOUTH AFRICA
}

Davis, K. ${ }^{1}$, Landini, F. ${ }^{2}$, van Niekerk, J. $^{3}$, Green, K. ${ }^{4}$ and Terblanche, S. E. ${ }^{5}$

Corresponding author: K. Davis. Email: k.davis@cgiar.org

\section{ABSTRACT}

Extension is evolving, and extension workers' roles and attitudes are changing with global realities. The purpose of this study was to examine South African extension officers' perceptions of their job, views on the objectives of extension, and conception of agriculture. A questionnaire was developed consisting of general demographic and Likert-scale questions regarding perceptions of extension. The survey was emailed to all South African based members of the South African Society for Agricultural Extension (SASAE). The study found that most extensionists considered extension as a professional or technical practice to improve farmer practices followed by those who consider it as "helping farmers" to improve their wellbeing. The most preferred methods and the area of actual practice were first group and second individual approaches. According to the respondents, productive modernisation aimed at productivity and profitability was the highest extension objective, followed by increasing farmers' knowledge through training. In addition, results provide evidence that extension institutions tend to support conventional agriculture, while extension workers are more concerned with potential negative impacts. Finally, the Likert-scale responses show that while much South African extension work is based on dialogue and horizontal coordination using a participatory approach, transfer of technology still exists, and farmers are blamed for their problems.

Keywords: Agroecology, Diffusion, Extension, Innovation, Perception

\section{INTRODUCTION}

Extension has been evolving and will continue to do so (Davis, 2008; Davis et al, 2018). Extension workers' roles and attitudes are changing with changing global realities (Davis \& Sulaiman, 2014). At the same time, extension is broadening and becoming more holistic. Extension and advisory services are defined here as "all the different activities that provide the information and advisory services that are needed and demanded by farmers and other actors in agri-food systems and rural development." (Christoplos, 2010:2).

\footnotetext{
${ }^{1}$ Senior Research Fellow, International Food Policy Research Institute, c/o University of Pretoria, Pretoria, South Africa, E-mail: k.davis@cgiar.org

${ }^{2}$ Independent Researcher, National Council of Scientific and Technological Research (CONICET), and Associate Professor, University of La Cuenca del Plata, Barrufaldi, Posadas, Misiones, Argentina, E-mail: landini_fer@hotmail.com

${ }^{3}$ Director, Centre for Sustainable Agriculture, University of the Free State, Bloemfontein, South Africa, E-mail: vNiekerkJA@ufs.ac.za

${ }^{4}$ Junior Lecturer, Centre for Sustainable Agriculture, University of the Free State, Bloemfontein, South Africa, E-mail: GreenK@ufs.ac.za

5 Senior Lecturer, Department of Agricultural Economics, Extension and Rural Development, University of Pretoria, Pretoria, South Africa, e-mail: fanie.terblanche@up.ac.za
} 
Development paradigms that have affected extension have changed over the decades. Extension was first influenced by the linear transfer of technology or diffusionist approach (Davis, 2008; Koutsouris, 2018). This approach assumed that researchers and technical experts had the responsibility to generate new technologies, extension workers to transfer them, and farmers to adopt them. In this context, farmers' empirical knowledge tended to be neglected. The diffusion of innovations theory has heavily influenced extension thinking and practice (Rogers, 1995). After this was viewed as sometimes ineffective and irrelevant, along with other criticisms (Rivera, 2001), paradigms shifted to more participatory, farmer-led or demanddriven models (Chambers, 1997; Scoones \& Thompson, 1994). Within this model, farmers' empirical knowledge and experience are acknowledged and revalued (Duveskog, Friis-Hansen \& Taylor, 2011), and the hierarchical linear relationship between extension workers and farmers was reshaped as a horizontal interactive one (Machado, Hegedus \& Silveira, 2006). An older paradigm on which this is partially built is Paolo Freire's educational concept of conscientisation, the view that rural people must be empowered to make their own decisions (Freire, 1970).

More recently, the complex and broad agricultural innovation systems thinking (Davis, Ekboir \& Spielman, 2008; Spielman, 2002) changed the way in which we think about innovation processes, from adoption of technologies to a process that takes place in the context of the coordination and articulation between multiple social actors with different types of knowledge, experience, and social roles (Klerkx, Van Mierlo \& Leeuwis, 2012; Moschitz et al, 2015). Thus, extension officers become facilitators of social learning and inter-institutional coordination (innovation brokers) (Leeuwis \& Aarts, 2011; Tarekegne et al, 2017).

It is important to note that the diversity of extension practices not only refers to extension models or approaches, but also includes preferred methods and extension objectives. With regards to preferred methods, four general types can be identified. The first two refer to the use of individual methodologies (generally acquiring the form of individual technical assistance), versus the use of group approaches, characterised by participatory processes or horizontal learning (Acunso et al, 2016). Beyond individual and group methodologies, extension practice has also acknowledged the importance of using mass media communication strategies such as radio, television, and more recently, internet and mobile phones as a way of reaching farmers and providing up-to-date information (Parvizian, Hosseinnejad \& Lashgarara, 2011). Furthermore, in the context of agricultural innovation systems and territorial development approaches, extension officers have also incorporated methodologies for facilitating coordination between different institutions and social actors in the context of rural development/ innovation platforms, a role in line with the idea of "brokering" (Klerkx \& Leeuwis, 2009).

Extension objectives are also diverse. Within a traditional transfer of technology approach, agriculture modernisation was the most important objective of extension workers (Altalb, Filipek \& Skowron, 2015). However, changes in extension and development models broadened the scope of extension practice. Different institutions incorporated many other objectives to extension practice, such as creation and strengthening of farmer organisations (Landini, 2016a), support to commercialisation of produce (Swanson \& Rajalahti, 2010), management and protection of natural resources (Vanclay, 2004), and development of farmers' entrepreneurship capacity (Stevens, 2017). 
Authors have frequently studied extension approaches and objectives of specific institutions, policies, and even countries (Minh, Larsen \& Neef, 2010; Moschitz et al, 2015). However, these studies usually neglect differences between extension officers working in the same programmes or institutions (i.e. interpersonal differences). Even though institutions constrain and guide extension agents' practices, it is also clear that agents have a margin for manoeuvring (Long, 2001) and thus contribute to shaping institutional practices (Landini et al, 2014). As a result, understanding the diversity of extension workers' individual approaches, perspectives and objectives will help with understanding their practices.

\section{PURPOSE}

The purpose of this study was to examine South African extension officers' perceptions of rural extension and innovation as part of an international study that also includes Argentina, Australia, Brazil, Chile, Mexico, New Zealand and Nigeria. The international study was conducted by researchers from the National Council of Scientific and Technological Research as well as the University of La Cuenca del Plata in Argentina, and supported by the Global Forum for Rural Advisory Services. The research objective was to understand the perceptions and opinions of extension agents regarding their work and context in South Africa. Further publications will compare the South African case to those of other countries.

\section{METHODOLOGY}

A conceptual framework to assess extension agents' perceptions and opinions on extension and innovation was developed and validated by 12 international experts from 11 countries. This framework was used to develop a questionnaire with a Likert-type scale. The scale was validated using exploratory and confirmatory factor analysis using a sample from Argentina (Landini \& Beramendi, 2018).

The self-administered questionnaire was translated from Spanish and validated by Englishspeaking extension experts from South Africa. It consisted of general demographic questions as well as Likert-scale questions regarding perceptions of extension and innovation.

The South African Society for Agricultural Extension (SASAE) is a professional membership association for extension agents in South Africa and beyond. It was thus considered an appropriate target for the survey. A list of all members of SASAE members residing in South Africa was obtained $(\mathrm{N}=285)$. Permission was obtained from SASAE to conduct the study. The survey was pilot tested among 13 members from one province to ensure reliability. As the questions were not changed after the pilot, we included their responses with the overall results. Respondents had the option to respond to the survey using an online platform or by completing a fillable PDF form. Emails were sent to the entire mailing list. Reminders were sent after three weeks. Data were entered into SPSS version 21 and analysed.

\section{RESULTS}

Out of the targeted 285 South African based members of SASAE, 43 respondents ( $30 \%$ female) successfully completed the questionnaire. The majority of respondents $(74 \%)$ currently work as advisors or rural extensionists. They had worked between 0-44 years as extension workers, with an average of 15 years. Respondent ages varied from 26 to 63 with an average of 44 years of age. 
Table 1 shows the educational level of respondents, and Table 2 indicates the organisational affiliation of respondents.

Table 1: Maximum educational level reached

\begin{tabular}{|l|c|c|}
\hline & Frequency & Percentage \\
\hline Post-secondary school & 2 & 4.7 \\
\hline University degree & 17 & 39.5 \\
\hline Master's degree & 19 & 44.2 \\
\hline Doctorate & 5 & 11.6 \\
\hline Total & $\mathbf{4 3}$ & $\mathbf{1 0 0}$ \\
\hline
\end{tabular}

Table 2: Type of current extension institution, organisation or company

\begin{tabular}{|l|c|c|}
\hline & Frequency & Valid percentage \\
\hline Public (universities excluded) & 25 & 78,1 \\
\hline Farmer organisation or association & 2 & 6,3 \\
\hline Independent advisor & 2 & 6,3 \\
\hline Other & 3 & 9,3 \\
\hline Total & $\mathbf{3 2}$ & $\mathbf{1 0 0}$ \\
\hline No response & 11 & \\
\hline
\end{tabular}

Table 1 shows that most respondents $(55.8 \%)$ have a master's degree or a doctorate, which is very high when compared to other developing countries (Landini \& Bianqui, 2014). Table 2 shows that most participants come from the public sector. Although these results cannot be generalised to all South African extension agents, high levels of education imply an important potential for the country, especially considering that they work in the public sector.

Following the demographic data, respondents were asked about their perceptions of extension, farmers, and innovation. A set of 26 questions were asked regarding the general perceptions of South African extensionists. The Likert-scale items ranged from one to five, with $1=$ strongly disagree, $2=$ disagree, $3=$ neither agree nor disagree, $4=$ agree, and 5=strongly agree.

Landini and Beramendi (2018) showed that the Likert-type scale had five factors. Factor 1 is named "Dialogue and horizontal coordination." It refers to multiple situations where different actors dialogue, interact, coordinate, and work together in a horizontal way to reach different ends in the context of extension practice. The items address the relationships between extension workers, farmers, researchers, and other social actors. Factor 2 is named "Transfer of technology," because it expresses an extension approach that follows the classic diffusionist model. Factor 3 is named "Blame on farmers". It includes items that affirm that farmers are passive, traditionalist, and have handout attitudes. Factor 4 refers to the degree to which extension workers support a participatory, farmer-led extension approach. Finally, Factor 5 (named "Self-critical attitude,") includes items that value individual reflection on practice, as well as asking farmers and peers for feedback on extensionists' work. In our sample, the Cronbach's Alpha of each factor was acceptable, ranging from 0.55 to 0.73 . 
Table 3: Likert-scale responses to perceptions of extension for the five factors

\begin{tabular}{|l|c|c|c|c|}
\hline & Minimum & Maximum & Mean & $\begin{array}{c}\text { Standard } \\
\text { Deviation }\end{array}$ \\
\hline FACTOR 1 Dialogue and Coordination & 3.71 & 5.00 & 4.45 & .34 \\
\hline FACTOR 2 Transfer of Technologies & 2.00 & 4.83 & 3.72 & .73 \\
\hline FACTOR 3 Blame on Farmers & 2.20 & 5.00 & 3.57 & .70 \\
\hline FACTOR 4 Farmer-led Extension & 2.00 & 5.00 & 4.08 & .70 \\
\hline FACTOR 5 Self-critical Attitude & 1.50 & 5.00 & 3.71 & .75 \\
\hline
\end{tabular}

The most valued extension approach by South African extensionists was Factor 1, based on dialogue and inter-institutional coordination. Participatory farmer-led extension (Factor 4) was also valued. In both cases, the mean was higher than four (which indicates an agreement with the factor). These results are important as they show that the extension approach of South African extension agents is in line with recommendations of international literature on the topic (Landini, 2016b). In addition, the results indicate that there was a fair amount of agreement with a traditional, diffusionist approach (Factor 1), and that there was also a slight tendency to blame farmers for their lack of progress (Factor 3). These are also significant results since current academic literature has heavily criticised transfer of technologies as an extension approach (Rivera, 2001). Similarly, the tendency to blame farmers for their problems is also worth considering as it shows the difficulty of extension agents to "put on the farmers" shoes" and understand their point of view. Understanding farmers' point of view is fundamental for providing contextualised advice. Finally, results also show that participants have a valuable degree of self-critical attitude, a fundamental aspect for reflecting on practice and developing new strategies to face problems (Landini \& Brites, 2018)

Respondents were asked to rank their most preferred to least preferred methods of working with farmers and with other social actors on a scale of 1 to 4 . Potential answers included working with individuals, working with groups, inter-institutional and coordination work, and mass media. They were also asked to list the actual methods that they used, with 1 being the most used and 4 being the least used. In this case, participants also had the opportunity to state that they did not use the method at all (5).

Table 4: Preferred and most used extension methods

\begin{tabular}{|c|c|c|c|c|c|c|c|}
\hline \multirow{2}{*}{ Type of extension work } & \multirow{2}{*}{ Mean } & \multicolumn{4}{|c|}{ Level of preference and use } & \multirow{2}{*}{$\begin{array}{c}\text { "I do not } \\
\text { use it" (5) }\end{array}$} \\
\cline { 3 - 7 } & & $\mathbf{1}$ & $\mathbf{2}$ & $\mathbf{3}$ & $\mathbf{4}$ & -- \\
\hline \multirow{2}{*}{ Individual } & Preference & 2.21 & $39.5 \%$ & $25.6 \%$ & $9.3 \%$ & $25.6 \%$ & -- \\
\cline { 2 - 8 } & Use & 2.05 & $37.2 \%$ & $34.9 \%$ & $14 \%$ & $14 \%$ & -- \\
\hline \multirow{2}{*}{ Group } & Preference & 1.93 & $34.9 \%$ & $39.5 \%$ & $23.3 \%$ & $2.3 \%$ & --- \\
\cline { 2 - 8 } & Use & 1.74 & $41.9 \%$ & $41.9 \%$ & $16.3 \%$ & --- & --- \\
\hline $\begin{array}{c}\text { Inter- } \\
\text { institutional } \\
\text { coordination }\end{array}$ & Preference & 2.44 & $20.9 \%$ & $23.3 \%$ & $46.5 \%$ & $9.3 \%$ & --- \\
\hline \multirow{2}{*}{ Mass media } & 2.42 & $25.6 \%$ & $16.3 \%$ & $51.2 \%$ & $4.7 \%$ & $2.3 \%$ \\
\cline { 2 - 8 } & Preference & 3.42 & $4.7 \%$ & $11.6 \%$ & $20.9 \%$ & $62.8 \%$ & --- \\
\hline
\end{tabular}

The most preferred method and area of actual practice was group work, followed by individual work. Interestingly, group extension work was more practised than preferred, and individual 
extension work more preferred than practised, perhaps due to institutional requirements. Interinstitutional coordination fell in third place, while mass media in the last place. Considering the importance of mass media (mobile phones and internet) for reaching greater audience numbers at lower costs, these results should be discussed among SASAE with the following potential discussion topic: Is public extension in South Africa missing opportunities to take advantage of the potential of mass media?

Next, respondents were asked to order three statements regarding the role of extension, with the aim of better understanding their professional identities. Results are displayed in Table 5.

Table 5: Perception of extension's role

\begin{tabular}{|l|c|c|c|c|}
\hline \multicolumn{1}{|c|}{ Statements } & Mean & $\mathbf{1}^{\text {st }}$ choice & $\mathbf{2}^{\text {nd }}$ choice & $\mathbf{3}^{\text {rd }}$ choice \\
\hline $\begin{array}{l}\text { 1. A rural extensionist is a worker or } \\
\text { professional that helps to improve } \\
\text { farmers productive, commercial or } \\
\text { organisational practices. }\end{array}$ & 1.56 & $58.1 \%$ & $27.9 \%$ & $14 \%$ \\
\hline $\begin{array}{l}\text { 2. A rural extensionist helps farmers to } \\
\text { increase their well-being and improve } \\
\text { their quality of life. }\end{array}$ & 1.72 & $32.6 \%$ & $62.8 \%$ & $4.7 \%$ \\
\hline $\begin{array}{l}\text { 3. A rural extensionist supports } \\
\text { farmers so that they are able to } \\
\text { overcome situations of injustice and } \\
\text { oppression. }\end{array}$ & 2.72 & $9.3 \%$ & $9.3 \%$ & $81.4 \%$ \\
\hline
\end{tabular}

Note: For calculating the mean, $1^{\text {st }}$ choice was assumed to be $1,2^{\text {nd }}$ to be 2 and $3^{\text {rd }}$ to be 3 .

The lower the mean, the more preferred the option is.

Most extensionists considered extension as a professional or technical practice to improve farmer practices followed by those who consider it as "helping farmers" to improve their wellbeing. There were also some who considered extension as a way to fight social injustice. These results contribute to understanding extension workers' identities and personal motivations. Considering the value given to "helping farmers", future research should assess the prevalence of paternalistic attitudes on the part of extension agents.

Furthermore, respondents were asked about their perceptions of the most important objectives of extension practice. They only had the opportunity to select three out of 10 options (Table 6). These results indicate what are considered the most important objectives by South African extensionists.

Table 6: Perceptions on the most important extension objectives

\begin{tabular}{|ll|c|}
\hline \multicolumn{1}{|c|}{ Objectives } & Percentage \\
\hline $\begin{array}{l}\text { 1. } \\
\text { Productive modernisation aimed at increasing productivity and } \\
\text { profitability. }\end{array}$ & 55.8 \\
\hline 2. Increasing farmers' productive and commercial knowledge through \\
training sessions.
\end{tabular}




\begin{tabular}{|c|c|}
\hline 5. Protection and management of natural resources. & 30.2 \\
\hline 6. Developing entrepreneurial and business capacity. & 25.6 \\
\hline $\begin{array}{l}\text { 7. Improving farmers' quality of life by helping them to have access to basic } \\
\text { services. }\end{array}$ & 23.3 \\
\hline $\begin{array}{l}\text { 8. Resolution of productive or commercial problems posed by farmers by } \\
\text { means of providing advice. }\end{array}$ & 23.3 \\
\hline 9. Creation and strengthening of farmer organisations. & 11.6 \\
\hline $\begin{array}{l}\text { 10. Provision of information regarding prices or climate in order for it to be } \\
\text { used for decision making }\end{array}$ & 4.7 \\
\hline
\end{tabular}

Productive modernisation aimed at increasing productivity and profitability was the highest objective, followed by increasing farmers' knowledge through training, both characteristic of a traditional transfer of technology approach. The importance of supporting commercialisation of produce in conventional markers appears third. In contrast, supporting the creation and strengthening of farmer organisations, a strategy commonly used to support alternative commercialisation channels, occupies ninth place, showing a clear preference for conventional commercialisation strategies. Finally, two growingly important objectives of rural extension worldwide are in the middle of the chart, namely protection and management of natural resources and development of entrepreneurial and business capacity.

Respondents were also asked about their own opinions with regards to agroecology versus conventional agriculture on a scale of 1-5, with agroecology being 1 and conventional being 5 . They were further asked about their perspectives of the organisations or institutions where they worked. Results are displayed in Figure 1.

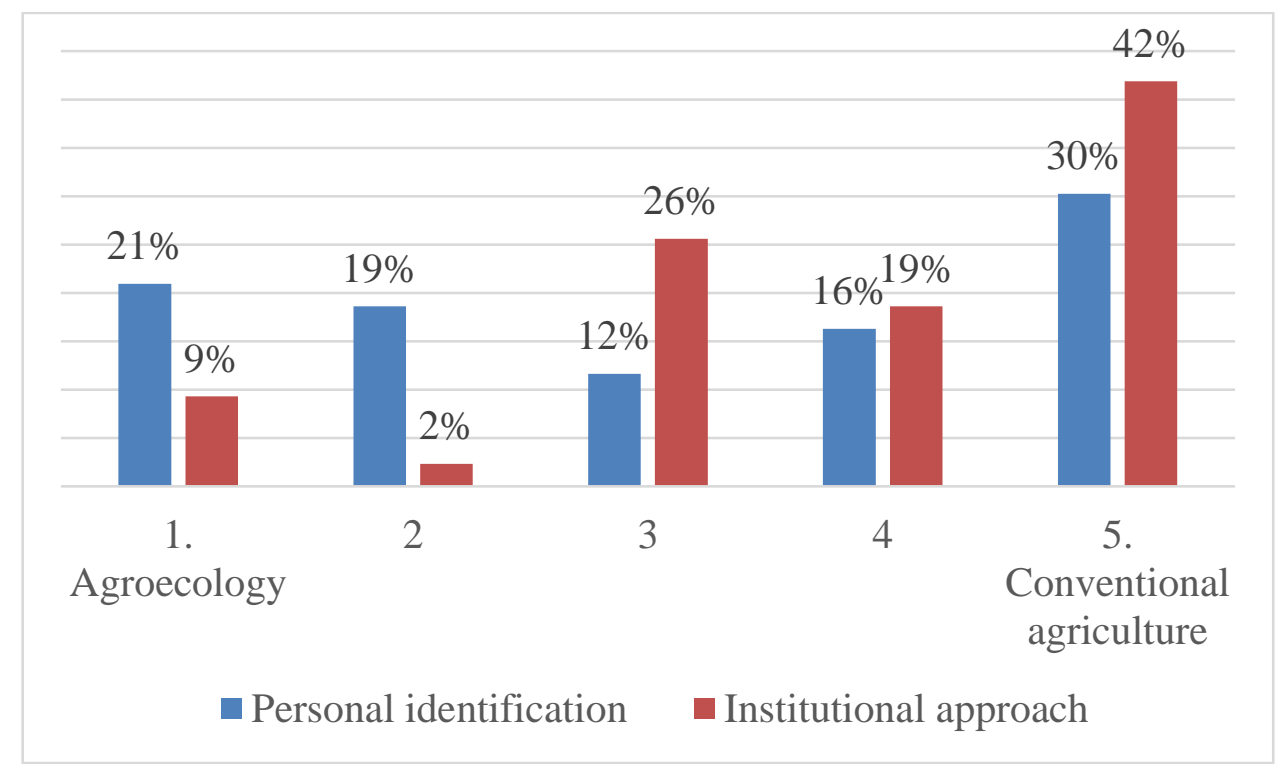

Figure 1: Productive approaches of extension workers and institutions

Results indicate that the extension agents most frequently prefer conventional modern agriculture $(30 \%)$. However, it is clear that there is no clear tendency towards one pole or the other, although only $12 \%$ of participants located themselves in a "neutral" position. This contrasts with the productive approach of their institutions, which seems to be clearly oriented to conventional agriculture. These results show that extension workers tend to be more concerned with potential negative effects of conventional agriculture than institutions. 


\section{CONCLUSION AND IMPLICATIONS}

Extension as a profession continues to evolve with varying attitudes and perceptions towards the profession around the world. As part of an international study, South African extensionists were surveyed regarding their perceptions of their job, their attitudes towards farmers, and their view on the objectives of extension and their conception of agriculture.

The South African extensionists were well educated in comparison with extensionists from other developing countries. They averaged 44 years of age and had an average of 15 years' working experience. Less than half of the respondents were female (30\%) whereas most of the respondents were working in the public sector (excluding universities).

The most valued extension approach by South African extensionists was Factor 1, based on dialogue and inter-institutional coordination. Participatory farmer-led extension (Factor 4) was also valued. There was a fair amount of agreement with a traditional, diffusionist approach (Factor 1). There was also a slight tendency to blame farmers for their lack of progress (Factor 3). The value given to inter-institutional coordination, to establishing horizontal relationships with farmers, and to participatory or demand-driven approaches are considered highly valuable by the international community. In contrast, the persistence of a diffusionist approach and the tendency to blame farmers leads to some concerns. In this line, extension workers' self-critical attitude constitutes a valuable resource to help to question traditional extension approaches (i.e. a transfer of technologies approach).

The most preferred methods and the area of actual practice were group and individual approaches, respectively. Group extension work was more practised than preferred, while individual extension work was more preferred than practiced. Inter-institutional coordination was selected in the third place and mass media in last place. Increasing the use of mobile phones and internet in rural extension may contribute to the increase in its effectiveness and efficiency.

Most extensionists considered extension as a professional or technical practice to improve farmer practices followed by those who consider it as "helping farmers" to improve their wellbeing. There were also some who considered extension as a way to fight social injustice. Additional research is required to understand whether the idea of "helping farmers" is due to a paternalistic attitude.

Regarding perceived objectives of extension, productive modernisation aimed at increasing productivity and profitability was the highest objective, followed by increasing farmers' knowledge through training. The centrality of these objectives may be connected to a traditional transfer of technology approach.

Finally, regarding their tendency towards either an ecological or a conventional approach, South African respondents were skewed slightly towards the conventional pole. However, at a personal level, extension practitioners in South Africa are much more agroecological in their approach than their institutions. This implies that they tend to be more concerned with potential negative impacts of conventional agriculture than the institutions where they work.

These results are important for extension in South Africa, especially SASAE, to take note of. The attitudes and opinions of extension affect their work and how they go about it. Extension 
institutions should examine their organisational perceptions of extension and innovation and see how best to equip their staff to meet the stated goals and objectives.

\section{REFERENCES}

ACUNZO, M., PAFUMI, M., TORRES, C. \& TIROL, M., 2016. Manual de comunicación para el desarrollo rural. Rome: FAO.

ALTALB, A.A.T., FILIPEK, T. \& SKOWRON, P., 2015. The role of agricultural extension in the transfer and adoption of agricultural technologies. Asian J. Agric. Food Sci., 3(5):500-507.

CHAMBERS, R., 1997. Whose reality counts? London: Intermediate Technology Publications.

CHRISTOPLOS, I., 2010. Mobilising the potential of rural and agricultural extension. Rome: FAO.

DAVIS, K., 2008. Extension in sub-Saharan Africa: Overview and assessment of past and current models and future prospects. JIAEE., 15(3):15-28.

DAVIS, K. \& SULAIMAN, V.R., 2014. The 'new extensionist': Roles and capacities to strengthen extension and advisory services. J. Agric. Educ. Ext., 21(3):6-18.

DAVIS, K., DOLLY, D., LAMM, A.J. \& LAMM, K.W., 2018. The future of extension: A network emergence perspective from the case of the Global Forum for Rural Advisory Services. JIAEE., 25(4):40-51.

DAVIS, K., EKBOIR, J. \& SPIELMAN, D.J., 2008. Strengthening agricultural education and training in sub-Saharan Africa from an innovation systems perspective: A case study of Mozambique. J. Agric. Educ. Ext., 14(1):35-51.

DUVESKOG, D., FRIIS-HANSEN, E. \& TAYLOR, E., 2011. Farmer field schools in rural Kenya: A transformative learning experience. J. Dev. Stud., 47(10):1529-1544.

FREIRE, P., 1970. Pedagogy of the oppressed. $30^{\text {th }}$ ed. New York: Continuum.

KLERKX, L. \& LEEUWIS, C., 2009. Establishment and embedding of innovation brokers at different innovation system levels: Insights from the Dutch agricultural sector. Technol. Forecast. Soc. Change, 76(6):849-860.

KLERKX, L., VAN MIERLO, B. \& LEEUWIS, C., 2012. Evolution of systems approaches to agricultural innovation: Concepts, analysis and interventions. In Farming systems research into the 21st century: The new dynamic (pp.457-483). Berlin: Springer.

KOUTSOURIS, A., 2018. Role of extension in agricultural technology transfer: A critical review. In From Agriscience to Agribusiness (pp.337-359). Cham: Springer.

LANDINI, F., 2016a. Enfoques y prácticas de extensión rural públicas en el noreste argentino. RESR., 54(1):167-186.

LANDINI, F., 2016b. How to be a good rural extensionist. Reflections and contributions of Argentine practitioners. J. Rural Stud., 43:193-202.

LANDINI, F. \& BERAMENDI, M., 2018. Construction and validation of a psychometric scale to assess extension agents' conceptions of extension and innovation. Manuscript under review. 
LANDINI, F. \& BIANQUI, V., 2014. Socio-demographic profile of different samples of Latin American rural extensionists. Cienc. Rural, 44(3):575-581.

LANDINI, F. \& BRITES, W., 2018. Evaluation and impact of a reflective training process for rural extension agents. J. Agric. Educ. Ext., 24(5):457-472.

LANDINI, F., LONG, N., LEEUWIS, C. \& MURTAGH, S., 2014. Theoretical guidelines for a psychology of rural development. Cuad. Desarro. Rural, 11(74):125-147.

LEEUWIS, C. \& AARTS, N., 2011. Rethinking communication in innovation processes: Creating space for change in complex systems. J. Agric. Educ. Ext., 17(1):21-36.

LONG, N., 2001. Development sociology: Actor perspectives. London: Routledge.

MACHADO, J.A.D., HEGEDUS, P.D. \& SILVEIRA, L.B.D., 2006. Estilos de relacionamento entre extensionistas e produtores: Desde uma concepçao bancária até o 'empowerment'. Cienc. Rural, 36(2):641-647.

MINH, T.T., LARSEN, C.S. \& NEEF, A., 2010. Challenges to institutionalizing participatory extension: The case of farmer livestock schools in Vietnam. J. Agric. Educ. Ext., 16(2):179-194.

MOSCHITZ, H., ROEP, D. BRUNORI, G. \& TISENKOPFS, T., 2015. Learning and innovation networks for sustainable agriculture: Processes of co-evolution, joint reflection and facilitation. J. Agric. Educ. Ext., 21(1):1-11.

PARVIZIAN, F., HOSSEINNEJAD, G.H. \& LASHGARARA, F., 2011. Investigating the role of radio and television programs on the improvement of agricultural extension. Am. J. Sci. Res., 16(1):6-14.

RIVERA, W.M., 2001. Whither agricultural extension worldwide? Reforms and prospects. In Knowledge generation and technical change: Institutional innovation in agriculture (pp.291-311). Boston: Springer.

ROGERS, E.M., 1995. Diffusion of innovations. $4^{\text {th }}$ ed. New York: The Free Press.

SCOONES, I. \& THOMPSON, J., 1994. Beyond farmer first: Rural people's knowledge, agricultural research and extension practice. London: Intermediate Technology Publications.

SPIELMAN, D.J., 2002. Innovation systems perspectives on developing-country agriculture: A critical review. ISNAR Discussion Paper No. 2. Washington, D.C., United States of America.

STEVENS, J.B., 2017. Is agricultural extension positioned to promote agripreneurship in South Africa? S. Afr. J. Agric. Ext., 45(2):86-94.

SWANSON, B.E. \& RAJALAHTI, R., 2010. Strengthening agricultural extension and advisory services. ARD Discussion Paper No. 45. Washington, D.C., United States of America.

TAREKEGNE, C., WESSELINK, R., BIEMANS, H. \& MULDER, M., 2017. Developing and validating a competence profile for development agents: An Ethiopian case study. $J$. Agric. Educ. Ext., 23(5):427-441.

VANCLAY, F., 2004. Social principles for agricultural extension to assist in the promotion of natural resource management. Aust. J. Exp. Agric., 44(3):213-222. 
